\title{
Investigating Local Definitions of Sustainability in the Arctic: Insights from Post-Soviet Sakha Villages
}

\author{
SUSAN A. CRATE
}

(Received 3 June 2005; accepted in revised form 21 October 2005)

\begin{abstract}
Contemporary survival for post-Soviet Russia's indigenous communities is complicated both by a Soviet legacy that undermined local ecological knowledge, kinship settlement patterns, land and resource rights, and robust ecosystems, and by the contemporary effects of globalization and modernity. Efforts to achieve sustainability lack a focus on local contexts, although recent research, especially in anthropology, underscores the need to develop sustainability criteria that are both flexible and adaptable to local contexts. Community-based research in post-Soviet Viliui Sakha indigenous communities of northeastern Siberia, Russia, has shown that inhabitants define sustainability as the building of local diversified economies, communities, and health via strong local leadership, a shared vision to work toward common goals, the reinstatement of local knowledge, and rights to land and resources. Realization of these ideas may be achieved by continued collaboration between circumpolar researchers and communities to facilitate the influx of ideas and models of success from other Arctic regions and by potential outcomes of intergovernmental action between the Russian Federation and its circumpolar neighbors through Russia's chairing of the Arctic Council. Implementation of flexible, locally adaptable sustainability criteria is central to these efforts.
\end{abstract}

Key words: indigenous peoples, sustainability, post-Soviet Russia, circumpolar cooperation, Sakha

RÉSUMÉ. La survie contemporaine des collectivités indigènes russes post-soviétiques est rendue complexe par un patrimoine soviétique qui minait le savoir écologique local, les tendances en matière de parenté, les droits à la terre et aux ressources, et les écosystèmes robustes, de même que par les effets contemporains de la mondialisation et la modernisation. Les efforts en matière d'atteinte de la durabilité ne portent pas suffisamment sur les contextes locaux, bien que des recherches récentes, notamment en anthropologie, fassent ressortir la nécessité d'élaborer des critères de durabilité qui sont à la fois souples et adaptables aux contextes locaux. Des recherches communautaires réalisées au sein des collectivités indigènes post-soviétiques de Viliui Sakha dans le nord-est de la Sibérie, en Russie, ont permis de constater que les habitants définissent la durabilité comme l'édification d'économies et de collectivités locales diversifiées et en santé grâce à un bon leadership local, à une vision partagée visant des objectifs communs, au rétablissement du savoir local et aux droits à la terre et aux ressources. La concrétisation de ces idées peut être rendue possible par une collaboration continue entre les chercheurs et les collectivités circumpolaires et ce, dans le but de faciliter l'apport d'idées et de modèles de réussites provenant d'autres régions de l'Arctique ainsi que par les résultats éventuels de mesures intergouvernementales entre la Fédération de Russie et ses voisins circumpolaires au moyen de la présidence du Conseil de l'Arctique par la Russie. Ces efforts reposent principalement sur la mise en œuvre de critères de durabilité souples et adaptables à l'échelle locale.

Mots clés : peuples indigènes, durabilité, Russie post-soviétique, collaboration circumpolaire, Sakha

Traduit pour la revue Arctic par Nicole Giguère.

\section{INTRODUCTION}

More than a decade after the fall of the Soviet Union, most of the Russian Federation's indigenous inhabitants continue to struggle daily with both the reality of failing political, economic, ecological, and social systems and the increasing pressures of globalization and modernity. Like their counterparts worldwide, they desire control over their lives, economies, and local resources, and hope for a sustainable future for their children and the coming generations. But what exactly is sustainable? In recent years, efforts to achieve sustainability are increasingly focused on what local communities need in their given cultural, environmental, and political contexts. This paper explores community-based research findings in indigenous areas of northeastern Siberia, Russia, to contribute to an emerging literature that supports the need for local definitions of sustainability.

The concept of "sustainable development" first became popular in 1987, when the Brundtland Commission defined the need for "development that meets the needs of the present without compromising the ability of future generations to meet their own needs" (WCED, 1987:43). Since that time the concept has gone through numerous reword-

${ }^{1}$ Department of Environmental Science and Policy, George Mason University, David King Hall, MS 5F2, 4400 University Drive, Fairfax, Virginia 22030-4400, U.S.A.; scrate1@ gmu.edu; http://mason.gmu.edu/ scrate1/

(C) The Arctic Institute of North America 
ings to be more inclusive and holistic and to enhance cultural and environmental priorities. Despite these refinements, however, efforts towards sustainability and sustainable development have most often become empty clichés of governments and policy makers (Jull, 2003). Critiques of sustainable development efforts spurred by the Brundtland report focus on the attempt to manage systems globally by an undefined "we" who know what is best for the world as a whole (Escobar, 1995). This, in turn, affirms a dominant Western top-down economic worldview that bases ecosystem management on generalized prescriptions rather than on specific contexts.

Researchers have recently been developing alternative approaches that defy conventional deductive reasoning by arguing that sustainability and sustainable development are not static prescriptions, but flexible discourses and meeting points for different ideas on how to achieve human betterment (Dryzek, 1997). If sustainability is a discourse about finding a balance between human and environmental systems so that the integrity of each remains intact, then it is intuitive that the conditions for such a balance will vary according to the specific local characteristics of ecosystem dynamics, cultural ways, and the interactions between the two. Furthermore, these interactions need to be dynamic and adaptable, "a livelihood is sustainable when it can cope with and recover from stresses and shocks, maintain or enhance its capabilities and assets, while not undermining the natural resource base" (Scoones, 1998:5).

Researchers, communities, and governments should look to more locally determined definitions of sustainability that are culture- and environment-specific, that can be locally conceived and maintained, and that are "shaped by particular historical and political-economic contexts" (Fratkin and Mearns, 2003:119). Anthropological research, with its emphasis on the needs and perspectives of local communities, contributes to an empirical basis for a more flexible understanding of sustainability and sustainable development. Although varying in its views of the concept, recent anthropological scholarship in the field does reach consensus that understanding local social systems is central to achieving sustainable ends (Stone, 2003). An example is the case of local fisheries management in the Brazilian Amazon reported by de Castro and McGrath (2003), which shows how local communities have innovated by replacing their conventional management system with community management based on accords that protect their fisheries from encroaching commercial fisheries. Contemporary research also reveals the capacity for cultural innovations to achieve more sustainable livelihoods. For example, North Tanzanian Maasai communities changed from pastoralist to agro-pastoralist subsistence strategies in response to the stresses of increasing human population, fluctuating livestock populations, reduced pastureland, and a mixed cash economy (McCabe, 2003). Clearly the emphasis on local definitions of what is sustainable is producing results. The challenge now is to develop flexible criteria that reflect local definitions of sustainability.

\section{SUSTAINABILITY AND INDIGENOUS PEOPLES}

In the last two decades, the cultural survival of the world's indigenous populations has received much attention, which, in its turn, has generated new understandings of what is meant by "sustainability" and "sustainable development." For "indigenous," I use the definition given by the International Labour Organization in Article 1, 1b of the Indigenous and Tribal Peoples Convention 1989 (ILO No. 169): "peoples in independent countries who are regarded as indigenous on account of their descent from the populations which inhabited the country, or a geographical region to which the country belongs, at the time of conquest or colonisation or the establishment of present state boundaries and who, irrespective of their legal status, retain some or all of their own social, economic, cultural and political institutions."

The Brundtland Report, which brought world attention to the concept of sustainable development, contained a detailed section on indigenous peoples that, among other things, clearly accused formal development projects of destroying the only cultures that were able to adapt in their environments (Jull, 2003). The section emphasized the need to recognize traditional rights and to protect the local institutions that manage resource use. Despite its official prescriptions, such understandings are absent from most governmental priorities.

Indigenous peoples are among the global inhabitants who are increasingly experiencing encroachment on their lives and lands in the wake of Western commercial and industrial expansion and population pressure. Their lands are often despoiled by adjacent environmental contamination and degradation. Yet indigenous peoples depend on these local ecosystems for subsistence and market resources, knowledge systems, settlement area, and a spiritual base. They have practical and ancestral mastery of their local natural environments, including an intimate understanding of climate, annual cycles, weather patterns, spatial distribution of resources, adaptive strategies, faunal migrations, and practical uses of animal, vegetative, and other renewable resources. This expertise is often termed "indigenous knowledge" and defined as "knowledge and values which have been acquired through experience, observation, from the land or from spiritual teachings, and handed down from one generation to another" (Abele, 1997:iii).

Indigenous discourses on sustainable management, founded on the complex relationships between land, nature, animals, subsistence practices, and their cyclical and spiritual aspects, have historically challenged Western scientific approaches that focus on the environmental management of discrete resources. Of late, indigenous knowledge is increasingly considered a highly valuable 
and often superior framework on which to build environmental management schemes. Take, for example, Principle 22 of the Rio Declaration, "Indigenous peoples and their communities, and other local communities, have a vital role in environmental management and development because of their knowledge and traditional practices. States should recognize and duly support their identity, culture, and interests and enable their effective participation in the achievement of sustainable development" (Quarrie, 1992:13). However, development projects often allow these peoples only two choices: to return to an ancient and "primitive" life way or to assimilate into a Western mode.

In the last decade, Native groups have made a claim to their resources, knowledge, and rights with a measure of success (Berkes, 1999; Dahl et al., 2000). These successes have also brought to light that sustainability for indigenous peoples does not end with improving the quality of their lives without compromising the future quality of life for their descendants: it also entails social and economic equity, cultural survival, and political devolution.

\section{Indigenous Sustainability in the Arctic Context}

Since World War II, circumpolar governments increasingly have penetrated territorial national northlands for access to resources, for construction of transportation corridors and facilities for education, health care, and administration, and for purposes of national defense. Concomitantly, Arctic indigenous peoples have defended their homelands and cultures (Jull, 2003). Thus the Arctic is a proving ground for localizing indigenous sustainability (Caulfield, 1997; Nuttall, 1998; Wilson, 1999; Sejersen, 2002; Habeck, 2003; Einarsson et al., 2004; Sirina, 2005).

Self-government (political devolution) and self-determination (the ability and right to live a particular way of life, to use language, to practice cultural or religious ways, and to determine economic development) are the central foci of indigenous sustainable development in the Arctic. The Alaska Native Claims Settlement Act (1971), Greenland Home Rule (1979), and the birth in 1999 of the Nunavut territory, designed to accommodate indigenous political aspirations and self-government, are prime examples of these efforts. These successes prove that indigenous peoples can gain rights to land and resources and serve as examples of indigenous sustainability in other Arctic and global contexts.

Many good examples of implementing local sustainability are found in the Arctic, especially co-management, a mode of resource management that draws upon both indigenous knowledge and Western science (Caulfield, 2000). Arctic communities use indigenous knowledge to guide planning for long-term management of subsistence resources (Nuttall, 1998). Arctic co-management is sustainable because it is tailored to local contexts and actors. A case in point is the Little Red River Cree Nation, which collaborated with social scientists to assess its situation and develop an adaptive, community-based management system that is responsive to the values, expectations, and changing needs of community members (Natcher and Hickey, 2002).

Other projects in the circumpolar North analyze contemporary indigenous practices to gauge long-term economic, ecological, and cultural sustainability (e.g., Anderson and Poppel, 2002). Many focus on empowering local resource users and integrating indigenous knowledge. One of them, the Sustainability of Arctic Communities Project, has as one objective to define sustainability in local cultural contexts. Project researchers analyzed local indigenous literature to identify five elements of sustainability that focus on building locally based economies, community infrastructures, and healthy lifestyles and are common to all four participating communities (Kofinas and Braund, 1996).

Circumpolar cooperation has facilitated local sustainability in the Arctic. The Arctic Eight states share common problems and have found ways to translate those shared concerns into ideas of sustainability. The greatest challenge for the Arctic Council, the governance body for circumpolar cooperation, is to link new developments in international Arctic cooperation within the overarching global framework of sustainable development. Recommendations to these ends include subsistence preference, co-management, and the development of environmentally appropriate technologies and practices (Nuttall, 1998).

\section{Indigenous Sustainability in the Russian North}

When the Russian Federation became an independent state in 1991, the worldwide priority of sustainable development was already codified in numerous international environmental conventions and documents (e.g., Club of Rome, 1972; IUCN, 1980; UNEP, 1982; WCED, 1987). The Russian government adopted sustainable development as a framework for economic and environmental decision making, incorporating it as a priority stance in official documents and government administration (Oldfield and Shaw, 2002). After this early introduction, however, the concept was lost in translation. The Russian term ustoichivoe razvitie translates to English as 'stable development' and has been understood in official rhetoric and policy as more akin to economic development than to sustainable development (Oldfield and Shaw, 2002). With Putin's 2000 abolishment of the Russian Federation State Committee for Environmental Protection and the melding of its responsibilities into the country's Ministry of Natural Resources, the Russian government abandoned its sustainable development ideals in favour of material gains (Peterson and Bielke, 2001; Henry, 2002).

Organizations concerned with environmental redress and cultural survival for Russia's indigenous peoples do exist. These groups, many of which are indigenous, are versed in citizen activism, including issues of environmental justice, through their contact and collaboration with adjacent northern countries (NRC, 2001). The contemporary conditions under which they are forced to live have prompted 
declarations that accuse the Russian government of discrimination and even genocide (Kohler and Wessendorf, 2002).

The classification of indigenous people in Russia differs from that used elsewhere the world. The 1925 Soviet classification of "small-numbered peoples" included peoples who practiced hunting, gathering, and reindeer herding and whose populations did not exceed 50000 (Slezkine, 1994:2). This category did not include the "numerically large" peoples including Komi, Yakut (Sakha), and Buriat (Shnirelman, 1999:119), although these same large-numbered peoples are classified as indigenous in global terms.

Marginal indigenous victories have resulted from the work of the Russian Association of Indigenous Peoples of the North (RAIPON), an alliance of Russia's numerically small peoples founded in 1990. With its central office in Moscow, the organization pursues its work with the Russian government. Much of RAIPON's success is due to international collaborations, most prominently its status as a permanent member of the Arctic Council and its special consultative status in the United Nations Economic and Social Council (ECOSOC). RAIPON has also improved its political and executive structure, primarily through funding from international projects (Kohler and Wessendorf, 2002). However, it is limited in its ability, and the plight of Russia's indigenous peoples worsens as President Putin focuses his country's economic policies on natural resource exploitation (Peterson and Bielke, 2001). The sacrificed health of indigenous rural populations is regarded as one price to pay for economic advance.

Comparative analysis of northern Russia's environmental and socioeconomic plight and that of other circumpolar cases has been ongoing for at least a decade (Chance and Andreeva, 1995). A survey of the progress in self-government and the degree of autonomy and selfdetermination among indigenous peoples of the Arctic reveals that the indigenous peoples of Russia are seriously lagging behind. In contrast to their circumpolar counterparts, Russia's indigenous peoples lack land claims and resource rights, as well as the political experience necessary to secure them. Also missing is strong leadership with vision and aspiration to cultivate the mindset of selfdetermination and self-government. This contrast is largely a result of history - the profound effects of collectivization and Sovietization-or, as Bruce Grant (1995:xiii) termed it so succinctly, "the last century of perestroikas."

The existing efforts to investigate indigenous sustainability in the Russian North have no aspect of working within local communities specifically to define sustainability (Krupnik, 1993; Pika, 1999; Jernsletten and Klokov, 2002). Local investigation is a crucial step. By working within communities and discussing what they and the coming generations need for a sustainable future, it should be possible to see what aspects of contemporary life do and do not work. The investigative process should also clarify the obstacles to achieving local definitions. The case reported here is an attempt to test this research approach.

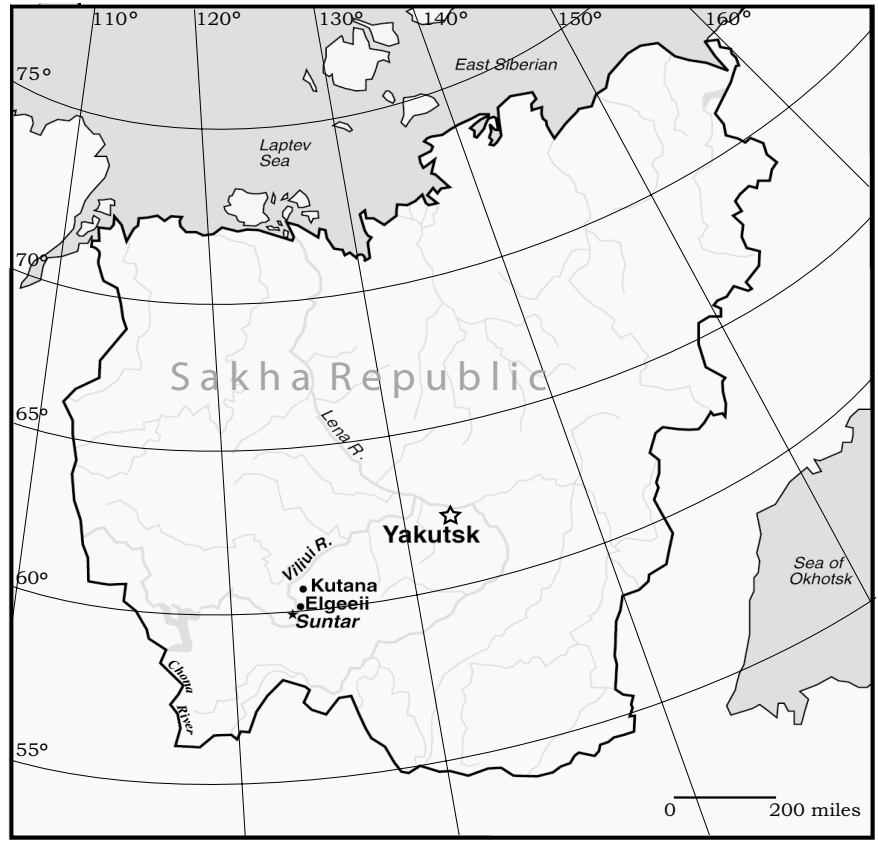

FIG. 1. The Sakha Republic, showing the capital city, Yakutsk, the Viliui River, the base research villages, Elgeeii and Kutana, and the Suntar regional center.

\section{INVESTIGATING INDIGENOUS SUSTAINABILITY IN POST-SOVIET VILIUI SAKHA VILLAGES}

This case study describes research with the Viliui Sakha, ethnic Sakha who inhabit the Viliui River regions of the western Sakha Republic in northeastern Siberia, Russia (Fig. 1). Sakha are a Turkic-speaking people who dwell in a Subarctic area that lies in approximately the same latitude range as Alaska. The climate is extremely continental, with an annual temperature range of $100^{\circ} \mathrm{C}$, from $-60^{\circ} \mathrm{C}$ in winter to $+40^{\circ} \mathrm{C}$ in summer. Historically, the majority of Sakha were horse- and cattle-breeders whose southern ancestors migrated north over 500 years ago, adapting their agro-pastoralist subsistence to the Subarctic ecosystem. Most contemporary rural Sakha continue to depend on cattle (and, to a lesser degree, horse) husbandry for subsistence and to generate some wages.

Village life is characterized by high unemployment (especially of males), delayed salaries, material shortages, and primitive living conditions lacking running water, toilets, paved roads, and central heating. Villages are home mostly to families: parents aged 25-45 raising children with their elder kin, mostly pensioners. In these intergenerational households, the elders supply childcare and the majority of cash for the household's mixed cash economy from their monthly pensions.

The Viliui regions are agricultural except for Mirnyi, which was established as an industrial region in the late 1950s, shortly after diamonds were discovered within its boundaries. To this day, these mines represent the major revenue-earner for the Sakha Republic. With the advent of diamond mining, local inhabitants, who already had been resettled several times to consolidate farming efforts in the 
early collectivization period, were brought into centralized agro-industrial state farm systems to supply milk and meat for the nascent diamond colonies. With the fall of the Soviet Union in the early 1990s, the majority of Viliui region state farms disbanded and divided their shares among employees and retirees. With rampant unemployment and lack of locally produced meat and milk products, most people have struggled for the last decade to develop modes of generating a cash income and producing food on a household level. Most have developed a "cows-and-kin" system, keeping a cow herd among several households and sharing the responsibilities for daily care and feeding requirements (Crate, 2003a).

Although the cows-and-kin system is an ecologically and culturally resilient subsistence mode for contemporary rural Sakha, the ongoing resource and transportation issues involved in keeping cattle, and the reports from youths and their parents of disinterest in cow-keeping, put its future in question. Similarly, unemployment continues to be a central issue in all Viliui Sakha villages. Aware of these issues, I initiated a research project in four Viliui Sakha villages, funded by the U.S. National Science Foundation and involving local research assistants, to investigate local definitions of sustainability and to clarify what barriers existed to realizing those ideas.

\section{Methodology}

The methods we employed were shaped by our practical skills and experience in these communities. I have conducted research with the Viliui Sakha communities of the Suntar region since 1991, administering surveys and interviews, recording oral histories, conducting time allocation studies and archival research, and being a participant observer. I am fluent in the Sakha language. I am married to a native Sakha from one of the research villages, who is an assistant on this project. Our history in these communities and our continuing involvement of local people as research assistants and consultants in evaluating the research results have established a level of trust with these communities that permits frank discussions of possible futures, local policies, and the limitations of science and local knowledge to predict the future.

Before entering the field, we developed materials based on our research findings since 1991. An important part of developing field materials was to find an appropriate term for "sustainability." We did not use the Russian word, since it carries the wrong meaning for these local contexts, as noted above. Instead, we used wording that emphasized local sustainability as a flexible discourse and meeting point for different ideas on how to achieve human betterment (Dryzek, 1997:123-125).

To define sustainability on a local level, we held focus groups in four Viliui Sakha villages in the summer of 2003, followed by semi-structured interviews to confirm the group responses and identify other issues. We chose to work in four villages that represented the range of popula-

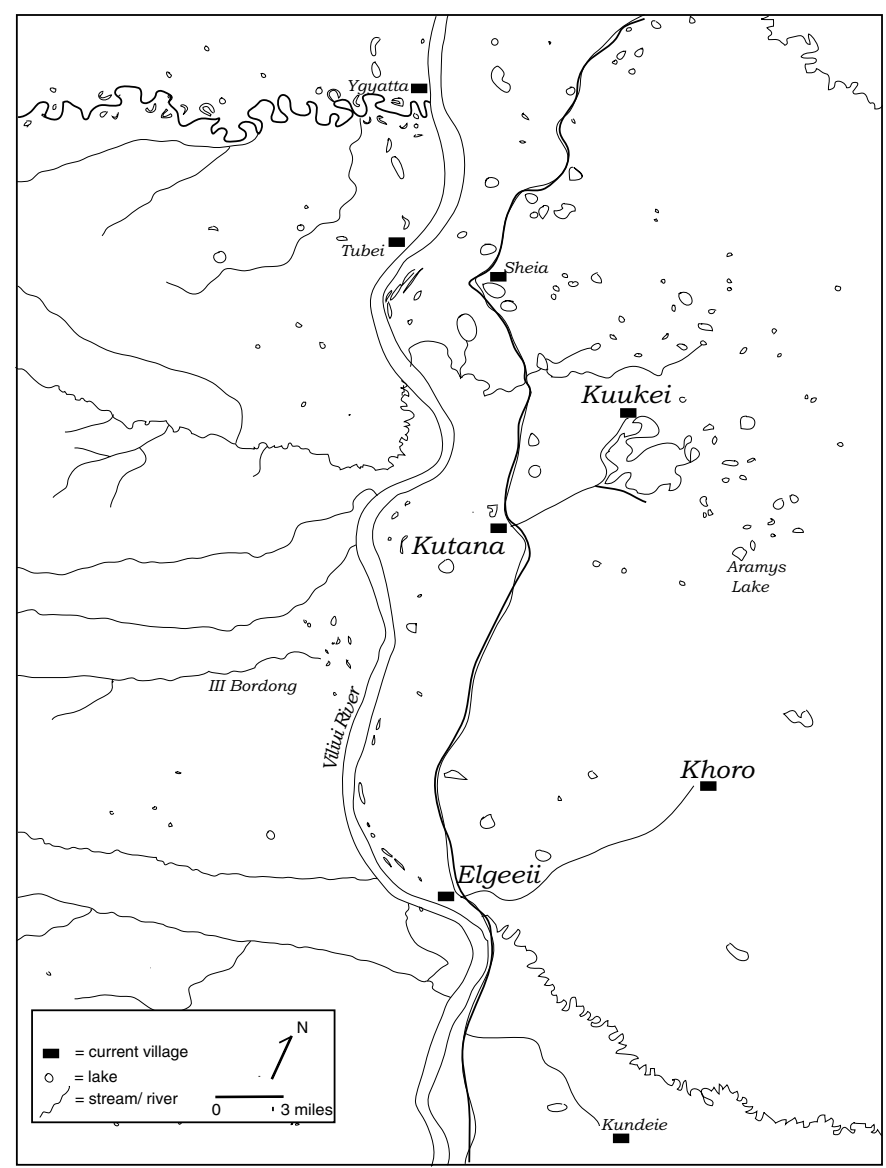

FIG. 2. The four research villages along the Viliui River: Elgeeii, Khoro, Kutana, and Kuukei.

tion densities found in the Viliui regions: the largest was Elgeeii (pop. 3000), then Kutana (1000), then Kuukei and Khoro, approximately 350 each (Fig. 2). The main effect of village population variance is in household-level resource access, specifically for cows-and-kin production, access to land for pasture, hay harvest, and other household resource access issues, including wood lots, hunting grounds, and foraging areas.

We had to schedule our time carefully in order to complete data collection before hay cutting began in midJuly, after which most inhabitants would be absent from the villages. In each village, we hired a research assistant, either one with whom we had worked previously or one recommended by our existing village contacts. Each village research assistant was responsible for selecting both focus group participants and the follow-up interviewees. In the second week of June, we met initially with all village assistants to explain the research plan and to task them with selecting participants who could best represent the socioeconomic range of their village population. Despite our stated desire for such a range, most participants were local intelligentsia. However, we do not consider this a fault in our work since the subgroup represents inhabitants who are informed and thoughtful about past and current local issues. 
In each village we organized two focus groups, one male and one female, made up of two members from each of three age groups, youth (age 18-25), middle age (26$54)$ and elder $(55+)$. We separated the groups by gender because our experience in the culture taught us that men and women speak more openly in their respective gender group. Immediately after the focus groups, we returned for interviews in each village to wrap up data collection by the second week of July. None of the interviewees had participated in the focus groups.

\section{The Focus Groups}

Each focus group met for one two-hour session in a common space, either a local museum or school. After explaining the goals of the project and the participants' right to anonymity, we began each session by asking participants to list their individual answers to two questions: 1) What do you and your household need to ensure a sustainable future? and 2) What does your community need to ensure a sustainable future? Participants had seven minutes to answer each question, after which we tallied their responses on a board for all to see. We then discussed four questions we had developed before entering the field, which were based on our research to date and concerned issues relevant to all villages: 1) What jobs do you need to resolve the unemployment problem in your village? 2) How can you work towards bettering the future of village youth? 3) How can you integrate the knowledge and survival strategies of your ancestors and contemporaries to contribute to your models of future sustainability? and 4) How can you bring your ideas about what you say you need for a sustainable future into reality?

Focus groups were consistent in their pattern of participant response across age groups. Elders were most talkative and youths the least. This pattern reflects Sakha respect for elders and could mean that the focus group method is problematic in this setting. We dealt with this concern in two concrete ways. First, we did have some success in evening out the input by giving all participants equal time to speak, which worked well except for male youths, half of whom didn't speak a word during the entire two-hour session despite our solicitations. Second, we followed up the focus groups with interviews to confirm group responses. In this context we were able to solicit male youths' responses directly in individual interviews.

\section{Focus Group Results:}

Tally of Focus Groups' Responses to Initial Questions

We organized the tallies from the eight focus groups under four broad themes that emerged in all discussions, grouping ideas according to their focus and including both the larger themes and specific projects under each theme (Table 1). We did not include the number of times each idea was voiced since this was a free-listing exercise and not intended to show statistical relevance.
The first three themes-developing diversified village economies, empowering the village community, and safeguarding community health-concerned the building of local capacities. The fourth, voiced mostly by elders, concerned soliciting continued support from the state to introduce subsidies for youth education and increase subsidies for disadvantaged elders (those without family to care for them). The first two themes coincide with a general awareness that the era of state paternalism is over and that decentralization means a re-localization of production and management. The third theme underscores local concerns about how health is affected not only by regional environmental issues but also by the spin-offs of economic decline that have generated increased alcohol and drug abuse and decreased nutrition. The final theme shows a residual clinging to paternalism, mostly voiced by elders with occasional votes by middle-aged participants for seed monies to start up local projects and businesses. In general, these results reflect a common desire for local control over their livelihoods and the resource inputs and production outputs of their local communities.

Respondents quoted in the following sections are identified only by sex and age group to protect their anonymity.

\section{Focus Groups' Responses: Resolving Unemployment}

Following the tally exercise, we began discussion of the four questions. The first focused question concerned resolving unemployment. In the post-Soviet context, Viliui Sakha households, like their rural counterparts across the Arctic, depend on a mixed cash economy, a combination of traditional subsistence production and cash inputs (Caulfield, 2000; Maher, 2004). Household economic characteristics from 2000 show that unemployment, lack of products, and decreased purchasing power has replaced the full employment, product availability, and fluid purchasing power of the Soviet period. Most household cash comes from state transfer payments in the form of salaries, pensions, and subsidies, and to a lesser extent from unofficial transactions.

The majority of salaried jobs are state-subsidized, whitecollar positions in administration, health care, and education. The rest are blue-collar and highly seasonal jobs, including shoveling coal for one of the many village furnaces or haying for a village cooperative. Half of all households depend on "freelance" or self-employed income, including odd jobs (cow-care for another household, seasonal house or barn building and repair, tractor hauling services for hay, firewood and ice, etc.); home crafts (reindeer boot manufacture and repair, tailoring, fur hat and coat making, quilt making, etc.); the sale of plant and animal products; and income from hauling hay, wood, or ice by tractor and truck. Most households depend on one or more pension incomes. Although the majority of pension income is from elder kin living in-house or within the immediate village, households also receive pensions for a range of invalid categories, for single parents, for widows, and for orphaned children. 
TABLE 1. Tally of focus group responses into larger themes.

\begin{tabular}{|c|c|}
\hline Larger Themes & Specific Projects under Theme \\
\hline To develop diversified village economies & $\begin{array}{l}\text { - Expand wage employment, via: } \\
\quad-\text { tourism } \\
\quad-\text { cottage industries (e.g., food processing, furniture making, sawmill) } \\
\quad-\text { local services (cafes, hairdressers, tailors) } \\
\quad-\text { other private businesses and professional employment } \\
\text { - Increase non-wage subsistence activity, such as domestic and wild food production; } \\
\text { - Provide practical training in job skills for village youth; }\end{array}$ \\
\hline To empower the village community & $\begin{array}{l}\text { - Develop common goals and a unified mindset by working in neighborhood groups ( } t \text { welben) for } \\
\text { village clean-up or family support groups } \\
\text { - Initiate cooperative food production by } \\
\quad-\text { localizing production of feed grain and garden produce } \\
\quad-\text { specializing farm production to increase animal numbers and use machinery efficiently } \\
\text { - Facilitate local governance by initiating native self-government to reinstate order, provide guidance for } \\
\text { youths, and assert family and community values } \\
\text { - Increase construction (especially private) to achieve housing equity for all }\end{array}$ \\
\hline To safeguard community health & $\begin{array}{l}\text { - Provide comprehensive health education } \\
\text { - Implement protection of nature to safeguard drinking water } \\
\text { - Start physical and spiritual culture programs, such as sport and ethics clinics } \\
\text { - Increase campaigns against drug and alcohol use }\end{array}$ \\
\hline To receive continued state support & $\begin{array}{l}\text { - Obtain state subsidies for youth education and displaced elders } \\
\text { - Introduce subsidies for community development, such as start-up funds for business and credit at low or } \\
\text { zero interest }\end{array}$ \\
\hline
\end{tabular}

Figure 3 shows the percentage of the 289 village households that I surveyed in 2000 that had 1) none, one, two, or three wage earners; 2) various levels of monthly total household salary income in rubles; and 3) none, one, two, or three pensioners. The source of wages is state salaries, which make up about half of a given household's monetary resources. The remainder comes from pensions, child subsidies, and money made through informal means. In 2000 , the total average household income was 2431 rubles (\$87 USD) per month. The official poverty-line indicator set by the state in 2000 was monthly income per household member of 1400 rubles (\$50 USD). Just to reach this minimum, a household of four would need to make 5600 rubles (\$200 USD) per month-more than twice the average income of the households surveyed.

Most households are involved in home food production, which compensates for a lack of monetary resources. Over half of all households keep cows and other domestic animals to produce meat, milk, and eggs. About $70 \%$ grow a substantial portion of their own food, and $65 \%$ forage, hunt, and fish to supplement domestic food production. Today, rural Sakha have increased their dependence on both pre-Soviet and contemporary household-level modes of food production to supplement the gap left by the shift from dependence on the socialist infrastructure for employment and consumer goods to the unemployment, poor distribution, and other economic hardships of post-Soviet times.

When discussing the need to resolve unemployment, participants were certain that job creation would bring households not only much-needed cash income, but also a suite of other benefits, including an increase in the local

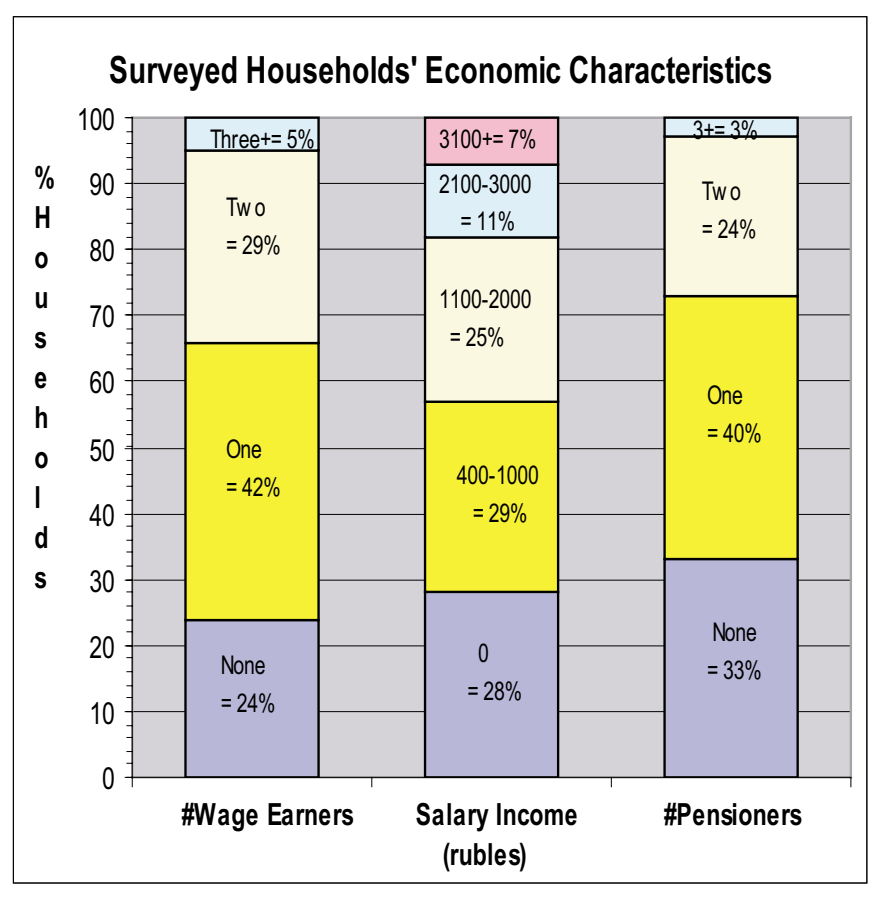

FIG. 3. Household income and employment characteristics relating to number of wage earners, salary income, and number of pensioners.

tax base that could be used to fund projects, employment for underemployed young people, and a decrease in alcohol abuse.

Participants considered the creation of local jobs the key to solving other local problems, such as that of generating taxes to fund local projects: 
... however many people are working...then the taxes will come into the government and through that we will have funds for culture and sport.... (middle-aged male)

Local job creation is seen as paramount to solving the problems of delinquent village youths and of attracting educated young people back to the village to stay:

Youth without work may go here and there and drink...but most youth are going for education - they already understand...they know they need to have salary. They won't come back here if there is no work.... (male youth)

Lastly, increasing local jobs was considered one pathway to decreasing village alcohol abuse: "If there are work places for all then we won't have the alcohol problem...if you are going to work the next day... why would you get drunk?" (middle-aged male).

Participants strongly voiced their opinion that jobs needed to be locally oriented in terms of their creation, the product base they relied upon, the demand they served, and their diversification. If inhabitants could develop a local economic base to create jobs rather than bringing in outside enterprise, they could recapture much of the added value of their vocations. Ideas for local economic development to increase employment included businesses to add value to raw products (e.g., milk and meat products) that the villages already were producing:

I think we need to build our own food processing plant...then we can make our own butter and products and turn these things around ourselves...we have a lot of animals... and so if we could build a mini-factory and process all these products we produce, that could be our first source of jobs and local wealth building. (middleaged male)

Similarly, many felt that the key to long-lasting employment was to develop businesses that are useful to the village populations and that use the natural and social capital that already exist in the village communities. One example was to organize a clothing factory, reminiscent of the bitovoi (literally "everyday necessity," the term used to refer to such factories in the Soviet period) that uses locally produced materials to make utilitarian clothing that villagers need and could use daily: "The products we get from other countries...they are bad... we need to get rid of [them]. We need to produce our own goods for our people" (male elder).

Finally, many mentioned the need for economic diversification. They felt the first step towards this was to consolidate village-level horse and cattle husbandry efforts into one or several small collectives. This consolidation would allow them to pool resources and equipment and form a farming sector that would supply the rest of the salaried community with animal products. Inhabitants also considered specialization important to maximize the resources particular to village conditions: "If we (Khoro, with lots of hay land for animals) could produce all meat and milk, [then] Elgeeii could do vegetables" (middleaged female).

The discussion of resolving unemployment included general comments about the barriers to realizing the ideas expressed. Many commented that despite the obvious need to work for themselves and to take the initiative to solve their own problems locally, lack of personal initiative would prevent this from happening:

In Elgeeii, one barrel of water costs 30 rubles - a very high price! [Residents either pay a truck to deliver water to their household or they haul it themselves.] It would be cheap to have water "provada" (lines). We have several $\mathrm{km}$ of water lines lying and not being used-we just need to make them. Also in Elgeeii there are 120 uninhabited lots. Neighboring households could use those lots to make more gardens, increase their animals, or just use it for pasture or hay .. . but our people need to be active. (middle-aged male)

Part of this discussion was about people's tendency toward apathy and overall lack of initiative to make ends meet:

It is all dependent on a person and how they go at their life...if they think they are going to be poor and if they wait for the state...they will never make it. If they have a small salary...they need to think of other ways to make ends meet...it all depends on the person and how they decide. (middle-aged female)

A second major barrier to resolving unemployment is the lack of start-up capital. Respondents had many ideas about developing the local economy to increase jobs. The real issue, most agreed, was that they needed initial funding. One source of that funding was the government:

The government could start us off and then the private businesses can take it up from there... maybe make clothes or produce food and process it...the specialists could come and teach us and we could get start up money and then the private people would take over with their profits. (middle-aged female)

Others voiced the opinion that start-up funds could come from overdue village-level compensation for the mineral and natural resources that the government exploits locally:

The diamonds, the gas, and the other resources that we have... we receive no percent but we should be living off a lot of that...we Sakha know we live over a very rich land with lots of resources under the ground... but other people from other lands come and take those resources and we never see them...China and Japan...they make the pipe to take our gas... but we live a few kilometers from the gas and don't see a bit of it. (male elder) 
This is an important point and one that most certainly needs to be further investigated to gauge how realistic it is, given the Sakha's lack of land claims and other territorial rights that allow such direct benefit agreements in other Arctic areas. Although ALROSA, the Russian-Sakha diamond company, agreed in 1993 to assign $2 \%$ of its revenues from diamond sales to a special fund for rehabilitation of environmental damage caused by the diamond mining and socio-economic development in the diamond province, most of these funds are used for building projects and never reach the communities most in need (Crate, 2003c).

As in the tallied responses, in our focused discussions about resolving unemployment, inhabitants emphasized the need for local economic diversification that would recapture the utility of available human, social, and natural capital. Job creation is viewed as a means to resolving other local issues, such as increasing local tax bases, employing young people, and alleviating alcoholism. However, barriers are significant and include a general apathy in populations to work towards these goals and a lack of start-up capital. One possible source of start-up capital is compensation for resource exploitation.

\section{Focus Groups' Responses: The Future of Youth}

The focused discussion about the future of youth centered on the lack of village-level youth employment. The youth unemployment problem is not due to lack of education. The majority of Viliui Sakha youths go on to get a higher education. Employment and opportunity are largely found outside rural Viliui Sakha villages, creating a pull to these places for both high school graduates and youths who desire work that uses their professional training. Additionally, the parents and relatives of high school graduates encourage them to leave the village for the regional or capital centers where they can get a degree and find employment.

Most youths who leave intend to get a higher education and return to their home village to work and raise a family, but they find no job opportunity to return to. They often cannot return for years, if at all, for lack of village jobs. Young people who stay or decide to return to the village despite the lack of opportunity are jobless and often delinquent. Some village youths (predominantly female) help their parents maintain the family cow herd, while others (mostly male) tend to be delinquent and unengaged.

Respondents agreed that if they could increase employment, this would attract young people back to the villages and engage those already there. They blamed the lack of youth jobs for generating other social problems, including delinquency, drug and alcohol abuse, suicide and homicide, theft, vandalism, and other crime. But who was to blame for the lack of jobs for young people? Participants blamed the village head, negligent parents, and the education system.

Many respondents felt that their village head was responsible: "The [village] head needs to find work for them...needs to find what talents the youth have and get them credit to start their own works.... and then they will be independent and already on their way with it" (middleaged male). Others blamed negligent parents for delinquent village youths:

You go to a household and the very healthy youth are sleeping...their parents are doing all the work...I see it...the old idea was that we use the strength of our youth to build the future. The youth now don't think about the future. There are many ways to develop our youth but we don't do them and so we don't get close to the youth...they are not with us. If someone's son brings in a few pieces of firewood, their parents will say, "Oh, look, our boy helps us!" So now all think that a strong, healthy 24-year-old boy who brings in one armful of wood is a huge helper... we don't teach our youth to work...we don't use their strength...we need to work with them and teach them. (male elder)

Still others blamed the education system. One male youth emphasized the need to bring more technology to the villages to support and teach the children and youth: "I think the best way [to get village youth more active] is to get the children involved in progress from early on. We need to have a phys-ed complex and we need lots of computers so that the young will progress... [We] need to bring in the internet and a movie theater."

The "blame" for youth unemployment and alienation is much more complex and multi-sided. Many of the Sakha's social problems, like those of other peoples of Russia's North, are founded in a Soviet legacy of disengaging families from the socialization and upbringing of their youth (Pika, 1999). In Viliui Sakha villages, this was achieved by farming children out to boarding schools and devaluing the knowledge and experience of pre-existing subsistence-based communities. In the Soviet period, youth could return and find work in their village's state farm operation or local administration. Now that crucial link is gone, and youth are either absent or jobless and delinquent.

\section{Focus Groups' Responses: The Use of Local Knowledge for Sustainability}

Our third focused question concerned how to transfer elder knowledge and survival skills that bolstered ideas of sustainability to the coming generations. Similar to the issues of delinquent youth, loss of local knowledge is a direct effect of a Soviet legacy that devalued the knowledge and experience of community elders. North Russian villagers need to make greater use of the experience and knowledge of nonprofessional teachers-people of older generations (Pika, 1999).

The processes of Soviet collectivization, agricultural industrialization, and acculturation worked to undermine Viliui Sakha local knowledge spatially, temporally, and socially. Contemporary elders, who know clan-based subsistence (albeit the majority were born after 1917, 
pre-Soviet practices did not change much until the early 1930s) early collectivization, state farm consolidation, and the break-up of the Soviet Union, straddle three worlds - the pre-Soviet, Soviet, and post-Soviet periods.

When interviewing elders about their past, I was surprised that their children and grandchildren showed little interest in what they remembered. On the other hand, such disinterest did coincide with the alienation of Sakha youth from both village life and their ancestral past. What do the youth - the grandchildren and great-grandchildren of these elders-know about their past? In Viliui Sakha villages, young people are not active in learning and carrying on the cultural history of their forebears.

Part of the reason for this is the orientation of folklore practice in the last century. During the Soviet period, the main focus of cultural preservation was collecting folklore rather than oral history as such. Soviet folklore research began in the mid-1940s with the goal to record all that was indigenous in order to transform it into propaganda for the Soviet party (Miller, 1990). Similarly, contemporary rural Sakha efforts to preserve the past are not geared towards recording individual accounts of the past (Cruikshank and Argunova, 2000). Elders and bearers of past knowledge continue to grow older, their memories continue to fade and be lost, and so also goes the local history. In the postSoviet context, elder knowledge is an invaluable resource for survival, but there are no local, regional, or state efforts to document, interpret, and use that resource (Crate, 2002). Instead, knowledge is lost for lack of time and resources to document, interpret, and disseminate it, and more importantly, because there is no local valuation for its utility in modern life.

What ways did participants suggest to revive and make use of the resource of local elder knowledge? First and foremost, they emphasized the need to reinstate the family as childrearer-a reinstatement of the pre-Soviet practice of the family as the central foundation in the upbringing of children:

In the Party (Soviet) time we were all considered children of the school... and now that has continued and I think it is a mistake... "whose child is that?". ... "Oh that's the school's child" ... where are the parents? ...no one knows who they are...the school is responsible for raising the children...but my opinion is that it is the parents and the family who are responsible now...instead, children have no parental input-often because the parents have no work...unemployed... and they drink and are poor. Their children do not study well... we have a lot of families like this. The children are strolling about at all hours of the night and their parents don't care or watch for them. (middle-aged male)

Second, participants agreed that the teaching and practice of Sier Twom (the Sakha's ancient belief system, based on respect for nature and fellow humans, and on love and stewardship of the birthland) was the best route to sustainability. Elders commented that most youth now do not know the old ways. For example, they do not know many hunting terms and lack knowledge and appreciation of self-reliance:

Before the Sakha lived off of cow and horse breeding and hunting...this was their way of survival. Their children learned this all from an early age. Our children now learn some of this...mostly the horse and cow raising. But the hunting...the youth go into the woods now and they can't hunt...they don't know the hunting terms, for example sokh-so (trap) ...what is that you ask and they don't have an idea...then ask the different kinds_-kili sokh-so, kelbete sokh-so, and they have no idea. Then the kwobakh aialakha (arrow trap for rabbits) and the cha-kan (bow trap) ...our youth have no idea what they are. They need to go with us hunting and learn about all this. Before, youth never hunted out of season. They fished and rabbit-hunted and duck-hunted... and knew all the seasons...now youth go fishing and they take the fish from another's ilim (fish net). (male elder)

Our focused discussions about reviving local elder knowledge to bolster village sustainability had much overlap with the previous discussions on youth. In both cases, participants emphasized the breakdown in continuity between generations that makes for an uncertain future and the concomitant need to reintegrate across the generations.

\section{Focus Groups' Responses: Bringing Ideas into Reality}

The final focused question asked how inhabitants thought they could bring their ideas of sustainability into reality. They emphasized three crucial factors: to develop a common mindset, to have strong leadership, and to realize protection and rights. The first two points reflect the communities' orientation to their Communist past. The context for this in our research villages is the success of the Elgeeii State Farm that won a Lenin Medal (Ordena Lenina), an honor given to only a handful of farms across the vast USSR for unprecedented growth in production. The personage credited for this success is the former Russian geologist turned farm director, Zhuravlev. Locally, Zhuravlev is remembered for bringing decent housing, medical facilities, preschool and boarding school facilities, and improved farm buildings and working conditions. The Elgeeii State farm boasted 229 workers who received medals and high acclaim across the USSR for their milking and meat-raising abilities. An additional 26 workers received the highest honors as workers within the Sakha Republic.

Then, with the 1991 fall of the USSR, the local community context changed drastically. Local state farm operations disbanded and farm resources were divvied up. Local Soviet elite transferred state farm resources, including machinery, animals, land allotments, and other capital reserves, to themselves, their kin, and their constituents. This reflected the rural village-level equivalent of the national trend towards "crony capitalism," the transformation of a majority of state 
capital into private hands (Rutland and Kogan, 2000:141). The remainder they divided among village households, resulting in an uneven allocation that left many without sufficient resources to generate household-level subsistence. People survived by pooling their resources with kin. The Soviet period incentive and precedence to work collectively was replaced with a post-Soviet priority to survive either through cronyism or kinship.

Although there is a trend toward personal initiative and entrepreneurship in the contemporary villages, people tend to adhere to a Soviet legacy of collective mindset and centralized administration. The most popular theme in our focus group discussion was the former, the need to cultivate a common mindset: "I think first of all we need to develop our mindset...so we are all thinking the same way and going the same way...so we can have meetings and people can talk about the way they want to see Elgeeii go and what work needs to be done. We have highly educated people here... a lot of potential" (middle-aged male).

In order to achieve that mindset, participants emphasized the need for strong leadership, again reminiscent of their Soviet past:

\begin{abstract}
We need a strong leader...someone who is interested in the people here and helping to live well on the resources here...how they appear and their life needs to be second place...first place are the people. It was like that in our [the Soviet] time. (male elder)
\end{abstract}

Participants felt that their village head should be a community organizer who works hard to 1) create jobs based on the skills and ideas of the village inhabitants, including delinquent youth; 2) secure funding from government grants for much-needed construction projects and start-up for local cottage industries; and 3) guide the village in its development of a productive community founded on common goals.

The third factor emphasized by participants as crucial to realizing their ideas of sustainability is to achieve protection and rights. They voiced a desire to gain rights to land, clean drinking water, and comprehensive environmental protection. In the local context, the abuse of and lack of such rights is a result of large-scale diamond development. This reflects a new way of thinking based on international models, especially from their aboriginal counterparts in Canada and the United States (Anderson, 2002). It is too early to say whether such thinking could bring about similar stakeholder arrangements between resource extraction industries and local communities.

\section{Semi-Structured Interviews}

We targeted the same three age groups for semi-structured interviews. The one-on-one character of the interviews allowed each age group equal time to respond to the issues. We conducted 15 interviews in each village, 5 with each age group, for a total of 60 interviews among the four villages.
Interviews were effective for further probing focus group findings and exploring other areas specific to future village-level sustainability including food security, environmental security, youth issues and making their ideas a reality. With reference to village-level food security, respondents made three main points: First, that cow-keeping will continue to be the main survival strategy in rural Sakha villages (contrary to competing ideas that with modernity, rural Sakha will abandon cow-keeping) because 1) it is Sakha's ancestral survival mode; 2) it is integral to Sakha cultural identity; and 3) it is the only way to have fresh products in the villages where transportation in the post-Soviet context is problematic.

A second food security issue that people discussed was the government's 2001 introduction of subsidies for home milk production. This is part of a larger, republic-wide project to raise the living standard in the villages, enabling cow keepers to receive income by selling their milk to a village milk station. The program is successful at bolstering household cash reserves and renewing interest in cow keeping for young families. However, many participants did voice concern that households with young children are selling all their milk for needed cash and depriving their children of necessary nutrition. The final food security issue discussed was the need to change how their villages kept cows to maximize the economies of scale through specializing cow care in collectives, thereby pooling resources (equipment, land, and labor) and providing salaries.

The main village-level environmental security issue was drinking water contamination. Although fully aware that regional diamond mining activities generate a complex of environmental issues, including drinking water contamination, inhabitants were reluctant to criticize it since it is the main source of state salaries, pensions, and other subsidies that form the cash basis of their mixed cash economies (Crate, 2003c). Respondents were vocal about other ecological issues, including the deforestation of adjacent woodlands from harvesting wood to heat homes, pasture deterioration due to overgrazing in the more populated villages, and the lack of proper disposal for commercial waste and excess manure.

Interview questions were identical across the three age groups except for youth, with whom we also discussed issues relevant to their, and thus their village's, future. Topics included youth unemployment, youth alienation from villages, youth propensity (or lack thereof) for cow keeping, youth knowledge of and ties to kin, and their valuation of elders' knowledge. The majority of youths interviewed were getting a higher education and said they planned to settle in their birth village if they could find work there. They agreed that the lack of village jobs needed to be resolved so they could return to their home villages to work and help improve the local economy and community. Several youths who were training to become schoolteachers commented that pensioned elders were monopolizing jobs for newly trained teachers by staying in village teaching jobs past retirement and "double-dipping" by receiving both salaries and 
pensions. This also impedes the advancement of educational content and methods in village schools, since young professionals trained in the latest advancements cannot enter into teaching positions.

The lack of jobs was not the only reason youth may not be returning to their home villages. Five of the twenty youths said they wanted to live in the city or regional center because villages are backwards and unprogressive and they want a better education for their children and better living conditions, like hot and cold running water and paved streets. This discussion fed into exploring youths' vision of their village's future. When asked how they thought their village would be in 20 years, a majority were hopeful that living conditions would improve, with new construction that offered central heating and water, and that this would keep inhabitants there and also attract new families. The other youth respondents said there would either be no change-that their village would be the same in 20 years as it is now, or that there would be both advances and declines.

Asked about their interest in keeping cows, a majority said they would keep cows because it was the best way to have fresh, healthy Sakha food and save their monetary resources for other needs. Middle-aged and elder respondents were doubtful that youth would take up cow care, commenting that their children were active in cow care until sixth grade, when their interest waned. After that time, the trend was to live off their parents' cow caring until the parents were elderly and physically unable to continue the vocation - only then would they take over. Perhaps youth will be motivated by the new monetary incentives of government subsidies for milk, mentioned earlier. It will be important to see if youths' stated intent to keep cows will become reality in the next few years when they finish their degrees and decide where to settle and how to live.

We also asked youths about their knowledge of ancestral kin. Most knew their ancestry only one or two generations back, a trend that stands in stark contrast to the Sakha tradition of knowing patrilineal kinship lines nine generations. However, this had no bearing on their ties to kin. All youth interviewees felt obligated to help their own or their kin's household with summer hay cutting, a critical part of rural Sakha subsistence survival. Further, most said they could not imagine village life without kin because helping and being helped by kin is the main mode of village survival. Several others said that village survival without kin is possible, but only with a good paying job and friends to fill the need for social support.

Youth interviews also gave us the opportunity to ask about the utility of elder knowledge. All but one of the twenty agreed that elder knowledge plays a vital role in future village sustainability. They argued that via elder knowledge individuals 1) compare their life with the past to gauge progress, to build upon former skills and wisdom, and to avoid past mistakes; 2) know local history, including genealogy, and can then pass that history on to future generations; 3) know how Sakha lived before and can thereby maintain cultural practices; and 4) know the place names and sacred areas of the local landscape and can actively maintain them. Youths directly associated elder knowledge with future sustainability because of its utility for contemporary subsistence and survival. They cited many examples of this knowledge, including information pertaining to horse and cattle husbandry; haying techniques; Sier Twom; nature protection and stewardship; medicinal plant use and other healing practices; clothing and textile manufacturing; hunting, fishing, and foraging practices; the building of utilitarian wooden structures and objects, including fences, houses, barns, and an array of other outbuildings used for subsistence horse and cattle-husbandry, as well as serge (horse-hitching posts which also have a spiritual function), chorons (ceremonial wooden chalices), and other containers; "country food" production (including uses of all animal parts and a wide array of milk foods); weather forecasting; and a love of work and occupation.

At the end of all interviews, we asked questions to check the responses received in the focus group setting, specifically by asking participants what they felt were the most important elements of future sustainability of their village. First, respondents said that a change of people's mindsetsto be thinking about how they can make their own lives better, how they can make work for themselves, how they can have the best relations with their neighbors and community members, and how they can work together to tackle common problems-was most important. Second, they said that village-level sustainability depended greatly upon keeping all inhabitants occupied; they referred not only to salaried employment, but also to entrepreneurial efforts and engagement in livelihood activities, including domestic food and agricultural production, hunting, fishing, foraging, construction, and crafts. Third, they said that sustainability depended on the ability of their village head to work with the people-that they needed a strong leader who spoke well and could guide the people and also get funding for needed projects. Several respondents, and all elders, put the main responsibility for future village sustainability on the government. Youths placed a great emphasis on community building - on the need to learn how to work together and coordinate efforts.

\section{Discussion and Next Phases of Research}

These results suggest that Viliui Sakha define sustainability as the building of local diversified economies, communities, and health via strong local leadership; a shared vision to work toward common goals; the reinstatement of local knowledge; and rights to land and resources. Not surprisingly, these statements are not much different from those made in other indigenous contexts; however, the ethnographic context, including the Soviet and post-Soviet legacy of these villages, and their dependence on a centralized government system until the recent past, renders these findings quite compelling. Inhabitants understand not only the need for local food production and consumption (reversing the Soviet trend of exporting all local production to adjacent urban areas and 
importing all village-level consumer goods), but also the necessity for other village-level economic activity. Such activity includes food processing; manufacturing of raw materials; the production of animal feed; the forming of small collectives to make cow and horse breeding efforts more efficient; and the development of entrepreneurial business activities, including tourism, service professions, and job training.

Additionally, most of the Sakha youths interviewed understood that the future is in their hands and that the key to having a productive and ample standard of living is to acquire some form of education beyond high school and to get a good job. This is a far cry from the apathy apparent among Sakha youths during the late Soviet/early postSoviet periods (Crate, 2002). Most do desire to return to their villages to work in their professions, but they face an immediate lack of village jobs. They appreciate and value knowledge of their elders and understand that it holds a central role in sustainable village futures.

However compelling these findings are, considering the novelty of these ideas and desires in the context of the Soviet and post-Soviet legacy, without action they remain for naught. This invokes a new set of questions. How can local communities realize their ideas of and desires for sustainable futures? What are individuals and households already doing to achieve these ends? What are the barriers, and are they surmountable? Lastly, how does this case differ from other circumpolar case studies, and how can international precedence work to bring about indigenous equity in the post-Soviet context? These questions form the basis for the continuation of this research project, a larger work in progress that involves several stages and is scheduled for completion in 2006. The first stage is to identify the impediments to local definitions of future sustainability by combining ethnographic and survey data to decipher what people are actually doing, how it is or is not sustainable, and what is preventing them from acting in more sustainable ways. This first stage will entail analyzing and assessing not only personal and household choices, but also infrastructural systems that are blocking local efforts. A second and parallel part of this assessment phase is working with youths and elders to document and integrate local knowledge into wider community use. Throughout these processes, village consultants will continue to work actively and provide key input on the various stages of the project, including the development of final community models for village sustainability.

\section{INDIGENOUS SUSTAINABILITY IN THE POST-SOCIALIST CONTEXT}

Research analyzing post-Soviet indigenous survival shows that native inhabitants of Russia have adapted to the conditions of the transition by reinstating some level of pre-Soviet subsistence strategies (Fondahl, 1998; Humphrey, 1998; Golovnev and Osherenko, 1999; Kerttula, 2000; Ziker, 2002; Crate, 2003a, b; Crate and Nuttall,
2004). The research described here shows that Viliui Sakha are not lacking in creative ideas on how to build sustainable futures for their communities and future generations. The real challenge is in realizing those ideas. Indigenous inhabitants of post-Soviet Russia share many similar needs with their global counterparts, but they also face many barriers. They lack the land and resource rights to instate local management and use, the politically experienced leaders needed to bring about native self-government, and the common mindset of self-determination to bring about change.

The past century of Sovietization and dependence on the state has left an indelible mark. Take, for example, the issue of local leadership. In the Soviet period, each village had a head of administration whose job it was to run the village for the central government. Towards the end of the Soviet period, many of these leaders assumed a less than honest work ethic, and when the Soviet Union fell, their general tendency was to misallocate most available local resources from the state farm and other village coffers. Call them mafia or not, many village leaders in the early post-Soviet context were characterized as self-interested and corrupt, redirecting much-needed state funding that was earmarked for local social service needs, and using village human resources to their own advantage (Crate, $2003 \mathrm{~b}$ ). In the contemporary context of a growing understanding and appreciation for the basic tenets of democracy, inhabitants increasingly call their village heads to account for their abuses and demand a fairer strategy for all. In this context, we could argue that inhabitants' desire for a strong leader to guide them in common goals and help them create local sustainable economies constitutes a formative stage of native self-government.

The main challenge of post-Socialist survival is adapting to rapid socioeconomic change, and inhabitants of the 26 post-Socialist countries have taken diverse approaches to resolving this problem in the last decade. Case studies underscore the need to "understand the perspective of ordinary people in the region, to look at the survival strategies and how people are coping in their new situations, the people who were supposed to be the empowered citizens of post-communist societies, but who have more often come to perceive themselves as victims" (Hann, 1997:xi).

For northern Russia's indigenous peoples, local contexts and conditions are shaped by a colonial legacy. Subjugation to the Russian imperial government began in the 17th century (Forsyth, 1992), and there had also been earlier cases of outside interference, like the attempt in 1383 by the monk Stefan Khrap to convert the Komi (Forsyth, 1992). Indigenous self-determination and sustainable subsistence practices were compromised by the introduction of new diseases, the demand for tribute payments in furs, and outsiders' encroachment on native lands (Wolf, 1982; Forsyth, 1992). Yet, however challenging and transformative the colonial period was for Russia's indigenous peoples, it was the Soviet period that brought 
more profound changes. Collectivization preempted a dependence on indigenous subsistence production, communal resource distribution, and clan-based land tenure and settlement patterns. Sovietization undermined indigenous culture, language, and spirituality. The socialist system created dependence on a central state that provided guaranteed employment, free education and health care, extensive social services, and access to consumer goods.

After three generations had adapted to the Soviet system, it ended in 1991. Over a decade later, most indigenous peoples still rely upon some form of pre-Soviet subsistence for day-to-day survival. For most it is a struggle, because local resources are not evenly distributed and cases of elite confiscation abound. Even if locals gain access to subsistence resources, a significant loss of their pre-Soviet subsistence knowledge, coupled with a dependence on Western mass media and consumer lifestyles, complicates a return to the land.

Geography plays both a negative and positive role in postSoviet indigenous survival. Collectivization transformed indigenous survival and settlement patterns from being subsistence-based and extensive across the landscape to being production-based and consolidated around central state farm operations. Ownership of production was replaced with collective, then state, ownership. State farm operations supplied foodstuffs for adjacent industrial complexes, which generated a variety of environmental casualties in local systems. In the post-Soviet context, landscapes are decidedly Soviet, characterized by centralized settlements and persistent environmental degradation. Inhabitants are largely unemployed and lack access to consumer goods, health care, and other social services. Geographic isolation, although never allowing for complete immunity to Soviet influence, did serve to facilitate a partial retention of kinship bases, spirituality, and indigenous ecological knowledge, all key elements of post-Soviet survival.

Most contemporary case studies of post-Soviet indigenous peoples conclude by portraying indigenous peoples as resilient survivors who, because they have retained preSoviet survival mechanisms (including dependence on kin-clan social systems, communal land tenure, and sharing), reemerge as the victors in the post-Soviet context. Humphrey (1998:482) describes Buriat pastoralists as survivors of the transition, not through adherence to Soviet blueprints, but through their collective enterprises, which combine a locally retained pre-Soviet reliance on clanbased economies with ideas from "globalized management-speak." Ziker (2002) explains how the Dolgan and Nganasan, hunters and fishers of the Taimyr peninsula, have revived their reliance on family-clan groupings, obliged sharing, and cooperation through informal and non-market relations to make up for the void left after the pullout of Soviet social and economic infrastructure. Golovnev and Osherenko (1999) detail the resilient characteristics of Nenets culture that were crucial to survival through the transition. These characteristics include extensive traditional knowledge systems; reliance on reindeer to provide most of their food, materials, and transport; and a non-consumer ethic that gives less importance to material possessions. Similarly, research analyzing the post-Soviet adaptive strategies of Viliui Sakha agropastoralists gives central importance to the reemergence of pre-Soviet lifeways, including household and interhousehold kin-based food production, clan-based horse and cattle breeding methods, and indigenous resource management strategies (Crate, 2003a).

Although these cases conclude with a message of hope for the future based on the resilience of indigenous lifeways, many of these same communities continue to struggle with issues of unemployment, a lack of cash resources, rampant alcoholism and drug abuse, poor schools and medical care, a native youth largely interested in modernity and Western culture, and pervasive environmental contamination of local subsistence resources. Clearly there is a need for analysis of the larger issues pertaining to environmental and social equity, indigenous rights, and local governance.

\section{TOWARDS SUSTAINABILITY?}

Despite the major hurdles that Russia's indigenous peoples face in building sustainable communities, there remains cause for hope. One source of hope comes from new and continued collaborations between circumpolar researchers and communities that, among other things, facilitate the influx of ideas and models of success from other Arctic regions. Although the Russian Federation's indigenous groups lack historical claims to territory that might be transferred into property rights, material compensation, and self-determination arrangements like those achieved in Greenland and Nunavut, similar arrangements could eventually follow as precedents and native rights movements cross international boundaries.

A second source of hope for realizing local desires and ideas of sustainability is the potential outcomes of intergovernmental action between Russia and its circumpolar neighbors through Russia's chairing of the Arctic Council. Established in 1996, the Arctic Council is an intergovernmental forum where the eight circumpolar countries can address common concerns, most prominently, the move toward environmentally, socially, and economically sustainable development. Six international organizations representing pan-Arctic indigenous peoples serve as permanent members on the council. In contrast to the conservation of environment and wildlife overtly emphasized in the early days of Arctic cooperation in the 1990s, issues concerning the lives and livelihoods of Arctic residents are now high on the agenda. Whether the Council is successful in achieving sustainability depends upon the extent to which it uses criteria sensitive to local conditions.

The Arctic Human Development Report (AHDR, 2004) has been identified as one effort that offers possibilities for further cooperation. Together with the Arctic Climate Impact Assessment (ACIA, 2004), the AHDR is illustrative of the 
kinds of Arctic Council projects that are establishing baselines for the knowledge needed to define more specific projects in social and economic development (Crate and Nuttall, 2004). The AHDR emphasizes the need to localize prescriptions for human development so they are better suited to the regions and cultures in question (AHDR, 2004). It also emphasizes the need to take advantage of interactions from the local to the global level in order to successfully achieve human betterment (AHDR, 2004).

Russia assumed the chairmanship of the Arctic Council for two years beginning in November 2004, giving the country an unprecedented opportunity to build on Gorbachev's legacy and emerge as a leader in circumpolar cooperation. (Although cooperation between the Arctic Eight had been evolving since the mid-20th century, many consider Mikhail Gorbachev's 1987 Murmansk speech, in which he declared the North a "Zone of Peace," to have been the critical moment that brought circumpolar cooperation into full force.) Russia could move the circumpolar cooperation agenda to new levels that deal constructively with the increased pressures, challenges, and opportunities related to globalization, economic development, and environmental change in local contexts throughout the circumpolar North.

One example is Russia's lead in formulating the Arctic Council's Sustainable Development Action Plan (SDAP) under the auspices of the Sustainable Development Working Group (SDWG). The plan presents real opportunities for decisive implementation of concrete sustainable development initiatives that will greatly improve the living conditions and economies of people throughout the Arctic. The preliminary work to develop an Arctic Sustainable Development Strategy (ASDS), while highlighting the distinct local issues that need to be addressed across northern areas, identifies four groups of issues: (1) managing human uses of the Arctic's living resources, (2) controlling the impacts of industrial activities in the Arctic, (3) enhancing community viability in the Arctic, and (4) protecting the Arctic from exogenous pressures (Young, 1998).

Expectations are high that the Arctic Council will act seriously on the policy recommendations resulting from the Arctic Climate Impact Assessment, while other significant initiatives with important development policy implications will be developed during Russia's chairmanship. One example is an assessment of potential impacts of oil and gas activities in the Arctic that will build on and expand the Arctic Monitoring and Assessment Programme (AMAP) report completed in 1997. The Arctic Council also gives Russia the opportunity to make a substantial contribution to the forthcoming Fourth International Polar Year (IPY4) in 2007-08, and Russia's leadership will be crucial in determining how this contribution can be defined and implemented.

Key to all these opportunities is the active and critical involvement of the international community of indigenous groups, researchers, and governmental bodies elsewhere in the circumpolar North who can facilitate the flow of ideas, experiences, and examples of indigenous movements across international boundaries (Crate and Nuttall, 2004). With continued international research collaboration between Russia and its circumpolar neighbors, and with Russia as chair of the Arctic Council, there is hope that future sustainability will become an increasing reality for Russia's indigenous peoples. Central to these efforts is the implementation of sustainability criteria that are flexible and adaptable to given local contexts.

\section{ACKNOWLEDGEMENTS}

I would like to acknowledge the people of the Viliui regions of western Sakha, Russia, without whose help my ongoing research would not be possible. The research documented in this article was supported by the National Science Foundation under Grant No. 0532993. Any opinions, findings, conclusions, and recommendations expressed in this material are those of the author and do not necessarily reflect the views of the National Science Foundation. I gratefully acknowledge and thank NSF. I also thank the several anonymous reviewers for their constructive feedback on an earlier draft.

\section{REFERENCES}

ABELE, F. 1997. Traditional ecological knowledge in practice. Arctic 50(4):iii-iv.

ACIA (ARCTIC CLIMATE IMPACT ASSESSMENT). 2004. Impacts of a warming Arctic: Arctic climate impact assessment. Cambridge: Cambridge University Press. 140 p. http://www. acia.uaf.edu.

AHDR (ARCTIC HUMAN DEVELOPMENT REPORT). 2004. Akureyri: Stefansson Arctic Institute.

ANDERSON, D. 2002. Entitlements, identity and time: Addressing Aboriginal rights and nature protection in Siberia's new resource colonies. In: Kasten, E., ed. People and the land. Berlin: Dietrich Reimer Verlag. 99-123.

ANDERSON, T., and POPPEL, B. 2002. Living conditions in the Arctic. Social Indicators Research 58:191-216.

BERKES, F. 1999. Sacred ecology: Traditional ecological knowledge and resource management. Philadelphia: Taylor and Francis.

CAULFIELD, R.A. 1997. Greenlanders, whales, and whaling: Sustainability and self-determination in the Arctic. Hanover, New Hampshire: University Press of New England.

- 2000. Political economy of renewable resources in the Arctic. In: Nuttall, M., and Callaghan, T., eds. The Arctic: environment, people, policy. Amsterdam: Harwood Academic Publishers. 485-513.

CHANCE, N.A., and ANDREEVA, E.N. 1995. Sustainability, equity, and natural resource development in Northwest Siberia and Arctic Alaska. Human Ecology 23:217-240.

CLUB OF ROME. 1972. The limits to growth. New York: Universe Books. 
CRATE, S. 2002. Viliui Sakha oral history: The key to contemporary household survival. Arctic Anthropology 39(1):134-154.

2003a. Viliui Sakha post-Soviet adaptation: A Subarctic test of Netting's smallholder theory. Human Ecology 31(4): $499-528$.

- 2003b. The great divide: Contested issues of post-Soviet Viliui Sakha land use. Europe-Asia Studies 55(6):869-888.

-2003c. Co-option in Siberia: The case of diamonds and the Vilyuy Sakha. Polar Geography 26(4) (2002):289-307.

CRATE, S., and NUTTALL, M. 2004. Russia in the circumpolar North. Polar Geography 27(2) (April-June 2003):85-96.

CRUIKSHANK, J., and ARGUNOVA, T. 2000. Reinscribing meaning: Memory and indigenous identity in Sakha Republic (Yakutia). Arctic Anthropology 37(1):96-119.

DAHL, J., HICKS, J., and JULL, P. 2000. Nunavut: Inuit regain control of their lands and their lives. International Work Group for Indigenous Affairs (IWGIA) Document No. 102. Copenhagen: IWGIA.

DE CASTRO, F., and McGRATH, D. 2003. Moving toward sustainability in the local management of floodplain lake fisheries in the Brazilian Amazon. Human Organization 62(2): $123-133$.

DRYZEK, J.S. 1997. The politics of the earth: Environmental discourses. Oxford: Oxford University Press.

ESCOBAR, A. 1995. Encountering development. Princeton: Princeton University Press.

FONDAHL, G. 1998. Gaining ground? Boston: Allyn \& Bacon.

FORSYTH, J. 1992. A history of the peoples of Siberia. Cambridge, United Kingdom: Cambridge University Press.

FRATKIN, E., and MEARNS, R. 2003. Sustainability and pastoral livelihoods: Lessons from East African Maasai and Mongolia. Human Organization 62(2):112-122.

GOLOVNEV, A., and OSHERENKO, G. 1999. Siberian survival: The Nenets and their story. Ithaca: Cornell University Press.

GRANT, B. 1995. In the Soviet house of culture: A century of perestroikas. Princeton: Princeton University Press.

HABECK, J. 2003. Sustainable development of the Pechora Region in a changing environment and society. Rovaniemi: University of Lapland. http://www.ulapland.fi/home/arktinen/spice/ spice.htm. Accessed 23 August 2005.

HANN, C. 1997. Foreword. In: Bridger, S., and Pine, F., eds. Surviving post-socialism: Local strategies and regional responses in Eastern Europe and the former Soviet Union. London: Routledge. $\mathrm{x}$-xiv.

HENRY, L. 2002. Thinking internationally, acting locally: The norm of sustainable development and the Russian environmental movement. Paper presented for the 2002 American Association for the Advancement of Slavic Studies Conference, 21-24 November, Pittsburgh, Pennsylvania.

HUMPHREY, C. 1998. Marx went away—but Karl stayed behind. Ann Arbor: University of Michigan Press.

ILO(INTERNATIONALLABOR ORGANIZATION). 1989. C169 Indigenous and Tribal Peoples Convention. http://www.ilo.org/ ilolex/cgi-lex/convde.pl?C169.

IUCN (THE WORLD CONSERVATION UNION). 1980. World conservation strategy. Gland, Switzerland: IUCN.
JERNSLETTEN, J.-L., and KLOKOV, K.B. 2002. Sustainable reindeer husbandry. Troms $\varnothing$ : Centre for Saami Studies, University of Troms $\varnothing$.

JULL, P. 2003. The politics of sustainable development: Reconciliation in indigenous hinterlands. In: Jentoft, S., Minde, H., and Nilsen, R., eds. Indigenous peoples: Resource management and global rights. Delft: Eburon Academic Publishers. 21-44.

KERTTULA, A. 2000. Antler on the sea: The Yup'ik and the Chukchi of the Russian Far East. Ithaca: Cornell University Press.

KOFINAS, G., and BRAUND, S. 1996. Defining Arctic community sustainability: A background paper prepared for the NSF Sustainability of Arctic Communities Project. http://www. taiga. net/sustain/lib/reports/sustainability.html. Accessed 23 August 2005.

KOHLER, T., and WESSENDORF, K., eds. 2002. Towards a new millennium: Ten years of the indigenous movement in Russia. Copenhagen: International Work Group for Indigenous Affairs.

KRUPNIK, I. 1993. Arctic adaptations. Dartmouth: University Press of New England.

MAHER, S. 2004. Traplines and tar sands: An ethnographic analysis of intersecting economies in a Subarctic Indigenous community. Cambridge, United Kingdom: Scott Polar Research Institute, University of Cambridge. http://www.spri.cam.ac.uk/research/ social/projects/maher.html. Accessed 23 August 2005.

McCABE, J.T. 2003. Sustainability and livelihood diversification among the Maasai of northern Tanzania. Human Organization 62(2):100-111.

MILLER, F. 1990. Folklore for Stalin. New York: Sharpe.

NATCHER, D., and HICKEY, C. 2002. Putting the community back into community-based resource management: A criteria and indicators approach to sustainability. Human Organization 61(4):350-363.

NRC (NATIONAL RESEARCH COUNCIL). 2001. The role of environmental NGOs: Russian challenges, American lessons: Proceedings of a Workshop. Washington, D.C.: National Academy Press.

NUTTALL, M. 1998. Protecting the Arctic: Indigenous peoples and cultural survival. Amsterdam: Harwood Academic Press.

NUTTALL, M., and CALLAGHAN, T.V., eds. 2000. The Arctic: Environment, people, policy. New York: Taylor and Francis.

OLDFIELD, J.D., and SHAW, D.J. 2002. Revisiting sustainable development: Russian cultural and scientific traditions and the concept of sustainable development. Area 34(4):391-400.

PETERSON, D.J., and BIELKE, E.K. 2001. The reorganization of Russia's environmental bureaucracy: Implications and prospects. Post-Soviet Geography and Economics 42(1):65-76.

PIKA, A.I. 1999. Neotraditionalism in the Russian North: Indigenous peoples and the legacy of perestroika. Seattle: University of Washington Press.

QUARRIE, J., ed. 1992. Earth Summit '92. London: Regency Press.

RUTLAND, P., and KOGAN, N. 2000. The Russian Mafia: Between hype and reality. In: Brown, A., ed. Contemporary Russian politics. Oxford: Oxford University Press. 139-147. 
SCOONES, I. 1998. Sustainable rural livelihoods: A framework for analysis. Working Paper 72. Sussex, United Kingdom: Institute of Development Studies.

SEJERSEN, F. 2002. Local knowledge, sustainability, and visionscapes in Greenland. Eskimologis skrifter nr. 17. Copenhagen: University of Copenhagen.

SHNIRELMAN, V. 1999. Introduction: North Eurasia. In: Blee, R., and Dalys, R., eds. The Cambridge encyclopedia of hunters \& gatherers. Cambridge, United Kingdom: Cambridge University Press: $119-173$.

SIRINA, A.A. 2005. Clan communities among the northern indigenous peoples of the Sakha (Yakutia) Republic: A step to self-determination? In: Kasten, E., ed. Rebuilding identities: Pathways to reform in Post-Soviet Siberia. Berlin: Dietrich Reimer Verlag.

SLEZKINE, Y. 1994. Arctic mirrors. Ithaca, New York: Cornell University Press.

STONE, M.P. 2003. Is sustainability for development anthropologists? Human Organization 62(2):93-99.
UNEP (UNITED NATIONS ENVIRONMENT PROGRAMME). 1982. World charter for nature. Nairobi, Kenya: UNEP.

WCED (WORLD COMMISSION ON ENVIRONMENT AND DEVELOPMENT). 1987. Our common future. Oxford: Oxford University Press.

WILSON, E. 1999. Conflict or compromise? Traditional natural resource use and oil exploration in northeastern Sakhalin/ Noglikskii District. In: Economic development and the environment on the Sakhalin offshore oil and gas fields II. Hokkaido: Slavic Research Center, Hokkaido University. 69-96. http:// src-h.slav.hokudai.ac.jp/sakhalin/eng/71/wilson. html. Accessed 23August 2005.

WOLF, E.R. 1982. Europe and the people without history. Berkeley: University of California Press. 503 p.

YOUNG, O. 1998. Creating an Arctic sustainable development strategy.http://www.svs.is/OranYoung.htm. Accessed 23 August 2005.

ZIKER, J.P. 2002. Peoples of the tundra: Northern Siberians in the post-Communist transition. Prospect Heights, Illinois: Waveland Press, Inc. 